\title{
Risicoaansprakelijkheid voor ongeschikte medische hulpzaken
}

\author{
Mr.dr. J.T. Hiemstra*
}

\section{Inleiding}

Op 4 oktober 2018 verdedigde ik mijn proefschrift over de aansprakelijkheid voor ongeschikte medische hulpzaken. ${ }^{1}$ Hoewel het gebruik van medische hulpzaken bij de behandeling van patiënten een onmiskenbare bijdrage levert aan de vooruitgang van de gezondheidszorg, kunnen hiermee ernstige risico's gepaard gaan. Vanwege het hoge ontwikkelingstempo en de complexe aard van medische hulpzaken zal de hulpverlener deze risico's niet altijd kunnen voorzien. De vraag is of, en in hoeverre, het risico dat voortvloeit uit het gebruik van een ongeschikte medische hulpzaak desalniettemin voor rekening van de hulpverlener dient te komen.

Ter beantwoording van die vraag heb ik het Nederlandse, Duitse, Franse en Engelse recht op dit punt onderzocht en een rechtseconomische analyse uitgevoerd. Om een kader te schetsen van de overige potentiële verhaalsmogelijkheden van de patiënt heb ik in mijn proefschrift tevens de mogelijke aansprakelijkheid van twee andere actoren besproken: de producent die de medische hulpzaak in het verkeer heeft gebracht en de notified body die de medische hulpzaak heeft gecertificeerd en daarmee toegelaten tot de Europese markt.

In dit artikel staat de aansprakelijkheid van de hulpverlener centraal. ${ }^{2}$ De vraag of het risico dat voortvloeit uit het gebruik van een ongeschikte medische hulpzaak voor rekening van de hulpverlener dient te komen, wordt reeds sinds de invoering van het Nieuw Burgerlijk Wetboek (NBW) bediscussieerd in de literatuur en verschillend beantwoord in de jurisprudentie. Een recent verschenen arrest van het Gerechtshof ArnhemLeeuwarden, waarin het hof deze vraag bevestigend beant-

Mr. dr. J.T. Hiemstra is advocaat te Amsterdam.

1. J.T. Hiemstra, De aansprakelijkheid voor ongeschikte medische hulpzaken (diss. Groningen), Deventer: Wolters Kluwer 2018.

2. In dit artikel wordt op de aansprakelijkheid van de producent en de notified body niet verder ingegaan en wordt volstaan met de opmerking dat in het onderzoek naar voren kwam dat verhaal van schade op deze actoren door de patiënt niet eenvoudig is. Dit heeft bij de producent onder meer te maken met beperkingen van het toepasselijke aansprakelijkheidsregime en praktische bezwaren. Bij de notified body heeft dit te maken met de moeilijkheden die gepaard gaan met het vaststellen van een toerekenbare onrechtmatige daad van een dergelijke certificeringsinstelling. Ook op de rechtseconomische analyse wordt hier niet verder ingegaan en wordt volstaan met de opmerking dat in het onderzoek naar voren kwam dat een risicoaansprakelijkheid van de hulpverlener voor het gebruik van een medische hulpzaak te prefereren is boven een schuldaansprakelijkheid. woordde, heeft de pennen opnieuw in beweging gebracht. ${ }^{3}$ In deze zaak is cassatie ingesteld en in een andere zaak zijn prejudiciële vragen gesteld, dus de Hoge Raad zal zich op korte termijn over dit vraagstuk uitlaten. ${ }^{4}$ In het navolgende zal ik de hoofdlijnen van de in mijn proefschrift verdedigde opvatting uiteenzetten.

\section{De aansprakelijkheid van de hulpverlener voor} het gebruik van een ongeschikte medische zaak

\subsection{Wettelijke grondslag}

In Nederland staan de hulpverlener en de patiënt in een contractuele verhouding tot elkaar die wordt gekwalificeerd als een geneeskundige behandelingsovereenkomst. De hulpverlener is op grond van artikel 6:74 Burgerlijk Wetboek (BW) aansprakelijk jegens de patiënt indien hij tekort is geschoten in de nakoming van een op hem rustende verbintenis, tenzij dit niet aan hem kan worden toegerekend. Een tekortkoming ontstaan door het gebruik van een medische hulpzaak kan ex artikel 6:75 BW an de hulpverlener worden toegerekend op grond van schuld indien de hulpverlener bij het gebruik van de hulpzaak niet de zorg van een goed hulpverlener in acht heeft genomen. Daarnaast kan een tekortkoming ontstaan door het gebruik van een medische hulpzaak ex artikel 6:75 jo. artikel 6:77 BW aan de hulpverlener worden toegerekend op grond van de wet. Artikel 6:77 BW bepaalt dat een tekortkoming ontstaan door het gebruik van een hulpzaak die ongeschikt is voor de uitvoering van de verbintenis aan de schuldenaar wordt toegerekend. Aan deze regel is een uitzondering toegevoegd in de vorm van een tenzij-formule: de tekortkoming ontstaan door het gebruik van een hulpzaak wordt niet aan de schuldenaar toegerekend indien dit onredelijk zou zijn. Toerekening kan op grond van de inhoud en strekking van de rechtshandeling waaruit de verbintenis voortspruit (par. 2.2.2), de in het verkeer geldende opvattingen (par. 2.2.3) of de overige omstandigheden van het (concrete) geval (par. 2.2.4) onredelijk zijn.

3. Hof Arnhem-Leeuwarden 29 november 2018, ECLI:NL:GHARL: 2018:10336. Zie hierover onder meer de annotatie van R.P. Wijne in dit nummer, de annotatie van J.P.M. Simons in JA 2019/4, de recensie van mijn proefschrift door M.J.J. de Ridder in MvV 2019, afl. 1, p. 6-14 en een annotatie van mijn hand, die in maart in $L \& S$ zal verschijnen.

4. Hof Den Haag 23 februari 2018, ECLI:NL:GHDHA:2018:166. 


\subsection{De tenzij-formule van artikel 6:77 $\mathrm{BW}$}

\subsubsection{Inleiding}

De tenzij-formule van artikel 6:77 BW vervult buiten de medische context een volstrekt andere rol dan binnen de medische context. Uit de jurisprudentie inzake de aansprakelijkheid voor een ongeschikte niet-medische hulpzaak blijkt dat een beroep op de tenzij-formule niet snel succesvol is. Slechts een beperking van de keuzevrijheid van de schuldenaar door de schuldeiser lijkt sinds het Vliegtuigvleugel-arrest het oordeel te kunnen rechtvaardigen dat toerekening van het gebruik van een ongeschikte hulpzaak aan de schuldenaar onredelijk is. ${ }^{5}$ De tenzij-formule functioneert buiten de medische context als een redelijkheidsexceptie en vervult een rol die anders, wanneer deze formule niet aan het artikel was toegevoegd, door de beperkende werking van de redelijkheid en billijkheid zou zijn vervuld.

In de medische context is de toepassing van de hoofdregel van artikel 6:77 BW daarentegen minder vanzelfsprekend en is een beroep op de tenzij-formule vaker succesvol. De aansprakelijkheid voor een ongeschikte medische hulpzaak wordt veelvuldig onredelijk geacht. ${ }^{6}$ De jurisprudentie inzake de aansprakelijkheid voor het gebruik van een ongeschikte medische hulpzaak staat daarmee lijnrecht tegenover de jurisprudentie inzake de aansprakelijkheid voor het gebruik van een nietmedische hulpzaak. Dit terwijl het buiten de medische context dikwijls om economische schade gaat en in de medische context om letselschade.

Het verschil in toepassing van artikel 6:77 BW in de nietmedische en medische context is in belangrijke mate het gevolg van de memorie van antwoord (hierna: MvA) bij artikel 6:77 BW uit de jaren zeventig.7 In de MvA komt naar voren dat toerekening van het gebruik van een ongeschikte medische hulpzaak aan een hulpverlener mogelijk zou kunnen worden afgewezen op grond van de tenzij-formule. Deze

5. Rb. Limburg 31 mei 2017, ECLI:NL:RBLIM:2017:4985.

6. Onredelijk: Hof Amsterdam 7 januari 1988, TvGR 1989/99; Rb. 's-Hertogenbosch 21 juli 2010, L\&S 2011/125; Rb. Arnhem 28 november 2012, ECLI:NL:RBARN:2012:BY6606; Rb. Zeeland-West-Brabant 15 januari 2014, ECLI:NL:RBZWB:2014:3600; Rb. Rotterdam 19 augustus 2015, ECLI:NL:RBROT:2015:6179; Rb. Amsterdam 20 januari 2016, ECLI:NL:RBAMS:2016:212; Rb. Oost-Brabant 4 januari 2017, ECLI:NL:RBOBR:2017:42; Rb. Amsterdam 24 mei 2017, ECLI:NL:RBAMS:2017:3491; Rb. Limburg 31 mei 2017, ECLI:NL:RBLIM: 2017:4981. Redelijk: Hof Arnhem 27 juni 2000, ECLI:NL:GHARN:2000:AK4321, VR 2002/112; Geschillencommissie Ziekenhuizen 27 februari 2001, ZIN00-0068; Hof Arnhem 22 februari 2005, TvGR 2005/44; Geschillencommissie Ziekenhuizen 15 mei 2006, TCR 2007, p. 91; Rb. Breda 3 januari 2011, ECLI:NL:RBBRE: 2011:BO9631; Hof 's-Hertogenbosch 25 november 2014, ECLI: NL:GHSHE:2014:4936; Rb. Limburg 17 november 2016, ECLI:NL:RBLIM:2016:11635; en zeer recent: Hof Arnhem-Leeuwarden 27 november 2018, ECLI:NL:GHARL:2018:10336.

7. Kamerstukken 1975/76, 7729, 6 (MvA). opmerking is zowel destijds als recent sterk bekritiseerd in de literatuur. ${ }^{8}$

In de navolgende paragrafen wordt per categorie van de tenzijformule uiteengezet welke omstandigheden leiden tot (on)redelijkheid van toerekening aan de hulpverlener.

\subsubsection{Inhoud en strekking van de rechtshandeling}

- De keuzevrijheid van de schuldenaar

In het kader van de inhoud en strekking van de rechtshandeling waaruit de verbintenis voortspruit, is de keuzevrijheid van de schuldenaar van belang. Een belangrijke rechtvaardiging voor de risicoaansprakelijkheid van de hoofdregel van artikel 6:77 BW is dat de schuldenaar de zaak kiest voor de uitvoering van de op hem rustende verbintenis. Indien de keuzevrijheid van de schuldenaar door de schuldeiser wordt gelimiteerd doordat de schuldeiser de zaak aan de schuldenaar heeft voorgeschreven, dan dient het risico van het gebruik van deze zaak voor rekening van de schuldeiser te komen en is toerekening aan de schuldenaar onredelijk. ${ }^{9}$ Van dit uitgangspunt kan worden afgeweken als er sprake is van een discrepantie tussen de deskundigheid van de schuldeiser en de schuldenaar en op

8. Zie o.m. R.M. Schoonenberg, De aansprakelijkheid voor gebrekkige medische hulpmiddelen; stand van zaken, TvGR 1987, p. 87, E.H. Hondius, Produktenaansprakelijkheid in het ziekenhuis, TvGR 1990/7, E.H. Hondius, De privaatrechtelijke rechtspositie van de patiënt, TPR 1995, p. 1679, P. Bergkamp, Contractuele aansprakelijkheid voor gebrekkige medische hulpmiddelen, in: W.C.L. van der Grinten e.a. (red.), Onderneming en nieuw burgerlijk recht, Zwolle: Tjeenk Willink 1991, C.H.M. Kleemans, Nieuw Burgerlijk Wetboek en gezondheidsrecht, najaarsvergadering van de Vereniging voor Gezondheidsrecht 1992, TvGR 1993, p. 151, S.C.J.J. Kortmann, De rechtsgronden voor aansprakelijkheid in geval van medische fouten, in: J.M. Beer, S.C.J.J. Kortmann \& L.H.D.J. Booij, Aansprakelijkheid voor medische fouten vanuit juridisch oogpunt bezien, Lelystad: Koninklijke Vermande 1991, B. Sluyters, Het nieuwe vermogensrecht en het gezondheidsrecht, in: A.G. Castermans e.a. (red.), Het Nieuw BW in functie: de invloed van het nieuwe vermogensrecht op tien bijzondere rechtsgebieden, Arnhem: Gouda Quint 1992, C.J.J.M. Stolker, Aansprakelijkheid voor bloedprodukten en bloedtransfusies, NJB 1995/19, C.J.J.M. Stolker, Nederlandse toestanden? Medische aansprakelijkheid en de Wet geneeskundige behandelingsovereenkomst, VR 1996 , p. 1-8, M.A. Goslings, Medische aansprakelijkheid: een stand van zaken, TvGR 1995/4, A.J. Van, De aansprakelijkheid voor gebrekkige medische hulpmiddelen - Implanon revisited, TVP 2011, afl. 2, p. 44-49, R.P. Wijne, Wie betaalt de schade van de patiënt in geval van een disfunctionerende prothese?, TvGR 2012/3, R.P. Wijne, Aansprakelijkheid voor zorggerelateerde schade, Den Haag: Boom Juridische uitgevers 2013, I.C. Timmermans, Contractuele aansprakelijkheid voor medische hulpzaken, VR 2014/13, I.C. Timmermans, Dient een zorgverlener in te staan voor de kwaliteit van borstimplantaten?, AV\&S 2015/4, Asser/ Tjong Tjin Tai 7-IV 2014/207 en 456, A.J. Zijlstra, Civiele ansprakelijkheid voor het gebruik van medische applicaties, TvGR 2016/7, J.A.P.M. Ansems, Aansprakelijkheid voor medische hulpmiddelen, Weert: Celsus 2017 en Hiemstra 2018. Zie ook de literatuur genoemd in noot 3 .

9. Rb. Zwolle 9 september 1998, Prg. 1998/5075, r.o. 7; conclusie van A-G Van Oosten voor het Vliegtuigvleugel-arrest (NJ 1968/102) (hij merkte ten aanzien van het verweer van Zentveld op dat het personeel van Fokker aan hem zou hebben opgedragen zijn kraan op een manier te bedienen die hij zelf niet wenste en dit, indien juist bevonden, tot toerekening van het risico aan Fokker zou moeten leiden), HR 25 maart 1966, ECLI:NL:PHR:1966:AC4642, NJ 1966/279 (Moffenkit). Zie ook art. 7:760 BW. 
de schuldenaar een waarschuwingsplicht rust. ${ }^{10}$ Als de schuldeiser een zaak kiest en de schuldenaar weet of behoort te weten dat deze zaak ongeschikt is voor de uitvoering van de verbintenis, dan kan hij zich niet beroepen op onredelijkheid van toerekening op grond van een beperking van zijn keuzevrijheid als hij verzaakt de schuldeiser in te lichten over deze ongeschiktheid. Dit is ook relevant in de medische context. De hulpverlener is als deskundige doorgaans beter in staat dan de patiënt om de risico's die gepaard gaan met het gebruik van een bepaalde zaak in te schatten. Indien hij meent dat een door de patiënt gekozen zaak ongeschikt is, zal hij de patiënt daarover dienen in te lichten en desnoods het gebruik van die zaak dienen te weigeren. Verzaakt hij daarin, dan zal hem geen beroep op de tenzij-formule vanwege een gebrek aan keuzevrijheid toekomen.

Daarmee is niet gezegd dat er geen situaties denkbaar zijn waarin het risico dat voortvloeit uit het gebruik van de hulpzaak voor rekening van de patiënt komt. Indien de hulpverlener erin slaagt te bewijzen dat de keuze voor een specifieke zaak geheel door de patiënt is gemaakt, de hulpverlener de patiënt heeft gewaarschuwd voor de risico's, de patiënt daarmee akkoord is gegaan en de hulpverlener geen beroepsmatige bezwaren heeft tegen het gebruik van de zaak, dan zou het redelijk kunnen zijn de schade voor rekening van de patiënt te laten komen en derhalve te oordelen dat toerekening aan de hulpverlener onredelijk is.

- Inspannings- en resultaatsverbintenissen

In de literatuur en jurisprudentie is bovendien waarde gehecht aan het verschil tussen inspannings- en resultaatsverbintenissen. ${ }^{11}$ Als grond voor onredelijkheid van toerekening is aangevoerd dat de centrale verbintenis die voor de hulpverlener uit de behandelingsovereenkomst voortvloeit een inspanningsverbintenis is. Deze inspanningsverbintenis zou inhouden dat de hulpverlener de zorg van een goed hulpverlener in acht dient te nemen. Ten aanzien van de uitkomst van de behandeling zou geen resultaat kunnen worden toegezegd of verwacht, aangezien het menselijk lichaam een ongewisse factor vormt en op het uiteindelijke resultaat van invloed is. Ook ten aanzien van gebruikte zaken in het kader van een behandelingsovereenkomst zou geen sprake zijn van een resultaatsverplichting: het ontbreekt de hulpverlener aan deskundigheid om in te staan voor de eigenschappen van de zaken die hij gebruikt, en hij is ten aanzien daarvan bovendien afhankelijk van de producent. Toerekening op grond van risico zou niet redelijk zijn indien

10. Vgl. art. 7:760 lid 2 jo. art. 7:754 BW.

11. A.E. Santen, De aansprakelijkheid voor de gebrekkige hulpzaak in het licht van de geneeskundige behandelingsovereenkomst, PIV-Bulletin 2013, afl. 3, p. 7; M.S.E. van Beurden, De (on)redelijkheid van toerekenen gebrekkigheid medische hulpzaak an arts of ziekenhuis, PIV-Bulletin 2015, afl. 2, p. 3; V.J.P. Ramaekers, Schade door een ongeschikte medische hulpzaak ex artikel 6:77 BW: een rechtsvergelijking met Frankrijk en Duitsland, TVP 2016, afl. 4, par. 2.2.2 en o.m. Rb. Amsterdam 24 mei 2017, ECLI:NL:RBAMS:2017:3491, r.o. 4.9. Zie ook Kamerstukken II 1975/76, 7729, 6, p. 70 (MvA). de hulpverlener de van hem verwachte inspanning heeft geleverd.

Bij deze argumenten kunnen de volgende kanttekeningen worden geplaatst. Als men relevantie toekent aan de kwalificatie van de verbintenis als inspannings- of resultaatsverbintenis, dan ligt deze relevantie enkel bij het vaststellen van de tekortkoming en niet bij de toerekenbaarheid. ${ }^{12} \mathrm{Om}$ te beoordelen of de door de schuldenaar geleverde prestatie afwijkt van de prestatie waartoe hij verplicht was, kan het relevant zijn om vast te stellen of hij een inspanning diende te leveren of voor een bepaald resultaat instond. Veelal zullen uit een overeenkomst meerdere verbintenissen voortvloeien en zal een overeenkomst zowel inspannings- als resultaatsverplichtingen bevatten. Anders dan in de literatuur en jurisprudentie bij tijd en wijle naar voren komt, kan de vraag of de verbintenis van de hulpverlener als inspannings- of resultaatsverbintenis gekwalificeerd dient te worden, niet in zijn algemeenheid beantwoord worden. Het begrip 'zorg' uit artikel 7:453 BW ziet op een verzameling verplichtingen die afzonderlijk gekwalificeerd dienen te worden. ${ }^{13}$ Zo zal op de hulpverlener die zich ertoe heeft verbonden het linkerbeen van de patiënt te amputeren de inspanningsverplichting rusten deze operatie zorgvuldig uit te voeren. Daarnaast zal op hem de resultaatsverplichting rusten het linkerbeen te amputeren. Het amputeren van het rechterbeen leidt tot een tekortkoming.

Ten aanzien van het gebruik van zaken zal op de schuldenaar dikwijls een resultaatsverbintenis rusten ten aanzien van de geschiktheid van die zaken. ${ }^{14}$ De omstandigheid dat een schuldenaar geen technisch deskundige is ten aanzien van de zaken die hij gebruikt, doet buiten de medische context niet noodzakelijkerwijs af aan het oordeel dat hij instaat voor de deugdelijkheid ervan als hij deze zaken gebruikt. ${ }^{15}$ Dit geldt ook voor de hulpverlener die als opdrachtnemer (tegen betaling) een verplichting tot het leveren van een dienst aangaat. Evenals andere opdrachtnemers dient hij daarbij in beginsel in te staan voor (bepaalde aspecten van) de zaken die hij gebruikt bij de uitvoering van zijn verplichting, zoals de geschiktheid ervan voor die uitvoering. Het menselijk lichaam als ongewisse factor speelt in dat kader geen rol.

Indien, al dan niet met behulp van de kwalificatie van de verbintenis als inspannings- of resultaatsverplichting, de tekortkoming is vastgesteld, komen we toe aan de toerekening. Bij de

12. Broekema-Engelen, in: GS Verbintenissenrecht, art. 6:74 BW, aant. 8; Asser/Sieburgh 6-I 2016/192.

13. Vgl. Kamerstukken II 1990/91, 21561, 6, p. 5 (MvA).

14. Vgl. J.Ph. Suijling, Inleiding tot het burgerlijk recht (deel 1, 2de stuk), Haarlem: De Erven F. Bohn 1934, p. 306; Ph.A.N. Houwing, De inhoud van de verbintenis en overmacht, WPNR 1953/4316-4324, nr. 15; L.E.H. Rutten, Nederlands burgerlijk recht. Verbintenissenrecht III, Zwolle: Tjeenk Willink 1967, p. 266; Annotatie G.J. Scholten bij HR 13 december 1968, ECLI:NL:PHR:1968:AC3302, NJ 1969/174.

15. Dat op de schuldenaar een resultaatsverbintenis rust ten aanzien van de geschiktheid van de zaken die hij gebruikt, geldt niet in alle gevallen. Immers, de omvang van het resultaat waarvoor de schuldenaar instaat, zal afhangen van hetgeen partijen zijn overeengekomen. 
vraag of een tekortkoming aan de schuldenaar kan worden toegerekend, maakt de wet geen onderscheid tussen de toerekening van een tekortkoming in de nakoming van een inspanningsverbintenis en de toerekening van een tekortkoming in de nakoming van een resultaatsverbintenis. ${ }^{16}$ In beide gevallen kan de tekortkoming aan de schuldenaar worden toegerekend op grond van schuld of risico en in beide gevallen kan er sprake zijn van overmacht. De stelling dat de kwalificatie van de verbintenis relevant is bij de beoordeling van de toerekenbaarheid op grond van artikel 6:77 BW dient dan ook te worden afgewezen. ${ }^{17}$ Ook bij de tekortkoming die het gevolg is van de schending van een inspanningsverplichting is toerekening aan de schuldenaar op grond van de hoofdregel van artikel 6:77 BW mogelijk. ${ }^{18}$ Niet valt in te zien waarom dit onderscheid enkel bij de beoordeling van de toerekening van een tekortkoming in de medische context relevant zou zijn en bij andere overeenkomsten (van opdracht) niet.

\subsubsection{Verkeersopvattingen}

- De aansprakelijkheid van de producent

In de MvA bij artikel 6:77 BW is opgemerkt dat het bij hulpzaken die door de producent met een gebrek in het verkeer zijn gebracht voor de hand kan liggen om de producent aan te spreken en een vordering jegens de hulpverlener af te wijzen. Hieruit rijst de vraag of de aansprakelijkheid van de schuldenaar op grond van artikel 6:77 BW moet worden gekanaliseerd naar de producent. Bij beantwoording van deze vraag kan betekenis worden toegekend aan de omstandigheid dat ook de aansprakelijkheid voor zaken van respectievelijk de bezitter en leverancier wordt gekanaliseerd naar de producent van de zaak. ${ }^{19}$ Daar staat echter tegenover dat de aansprakelijkheid van de aannemer van werk voor gebruikte zaken niet wordt gekanaliseerd naar de producent van de zaak. Bij de vraag of een kanalisatie in het kader van artikel 6:77 BW dient te gelden, is onder meer relevant dat de verbintenis van de schuldenaar die een hulpzaak gebruikt dikwijls strekt tot het verlenen van een dienst of het verrichten van werk en daarmee sterke gelijkenissen vertoont met de verbintenis van de aannemer van werk. ${ }^{20}$ De verbintenis van de schuldenaar die een hulpzaak gebruikt, vertoont in mindere mate overeenkomsten met de verbintenis van de leverancier - die slechts als een doorgeefluik fungeert - en de positie van de bezitter. Dit zou tegen een kanalisatie in het kader van artikel 6:77 BW kunnen pleiten.

16. F.H.J. Mijnssen, Fouten van hulppersonen in contractuele en pre-contractuele verhoudingen, Alphen aan den Rijn: H.D. Tjeenk Willink 1978, p. 19-20; Asser/Tjong Tjin Tai 7-IV 2014/207. Tenzij de kwalificatie van de verplichting als resultaatsverplichting samenhangt met een door de schuldenaar gegeven garantie.

17. Het zou bovendien in een cirkelredenering resulteren.

18. Vgl. Asser/Tjong Tjin Tai 7-IV 2014/207.

19. T. Hartlief, Medische hulpmiddelen en de prijs van een bijzonder regime, NJB 2015/1187, p. 1639.

20. Asser/Tjong Tjin Tai 7-IV 2014/207; Kortmann 1991, p. 27.
Daar komt bij dat er krachtens het regime van de Richtlijn productaansprakelijkheid (hierna: Richtlijn) een belangrijk verschil bestaat tussen de aansprakelijkheid van de verkoper (leverancier) en de aansprakelijkheid van de hulpverlener of de aannemer van werk. Doordat de beoordelingsmarge van de lidstaten ten aanzien van de aansprakelijkheid voor gebrekkige producten volledig door de Richtlijn wordt bepaald en de leverancier onder de reikwijdte van de Richtlijn valt, mag het nationale recht geen aansprakelijkheid van de leverancier jegens de consument aannemen die afwijkt van de wijze waarop de Richtlijn de verhouding tussen de producent en de leverancier heeft geschetst. ${ }^{21}$ Dit betekent dat het nationale recht geen risicoaansprakelijkheid aan de leverancier mag opleggen op gelijke voet als de aansprakelijkheid van de producent. Dit regime geldt niet voor actoren wier juridische positie niet door de Richtlijn wordt gereguleerd. Een schuldenaar die bij de uitvoering van een dienst een gebrekkig product gebruikt waarvan hij niet de producent is, zoals de hulpverlener of de aannemer van werk, valt buiten de werkingssfeer van de Richtlijn en de Richtlijn verzet zich niet tegen een nationale regeling die voorziet in de risicoaansprakelijkheid van een dergelijke dienstverlener. 22

Dat een hulpverlener bij het ontbreken van een kanalisatie in een beknelde positie terecht zou kunnen komen - hij kan geconfronteerd worden met een exoneratie van de producent, terwijl hij zijn aansprakelijkheid jegens de patiënt niet uit kan sluiten -, is mijns inziens geen reden voor het aannemen van een kanalisatie. Dit zou namelijk impliceren dat de patiënt zijn contractuele wederpartij niet aan kan spreken omdat die zich kan verschuilen achter de omstandigheid dat zij akkoord is gegaan met een exoneratie van een leverancier of producent. Dit lijkt niet aan te sluiten bij een van de ontstaansredenen van artikel 6:77 BW: de schuldenaar zou zich niet achter anderen, zoals leveranciers en producenten, moeten kunnen verschuilen. ${ }^{23}$ Indien de hulpverlener ervoor heeft gekozen om zijn mogelijkheid tot verhaal te beperken door akkoord te gaan met een vrijtekeningsbeding in zijn overeenkomst met een producent, komt dat voor zijn rekening en dient hem dat niet een verweer te verschaffen jegens een andere contractuele wederpartij, de patiënt. ${ }^{24}$

Vanuit het oogpunt van consumentenbescherming pleit tegen een kanalisatie bovendien dat een vordering tot schadevergoe-

21. HvJ EG 25 april 2002, C-52/00, r.o. 16 (Commissie/Frankrijk); HvJ EG 25 april 2002, C-154/00 (Commissie/Griekenland); HvJ EG 25 april 2002, C-183/00 (González Sánchez); HvJ EG 10 januari 2006, C-402/03 (Bilka/Mikkelsen).

22. HvJ EU 21 december 2011, C-495/10.

23. Kamerstukken II 1970/71, 7729, 4, p. 11 (VV).

24. Vgl. Hondius 1990, par. 6; Ansems 2017, p. 71. Bovendien biedt art. 6:233 lid 1 of 6:248 lid 2 BW mogelijk soelaas aan de hulpverlener in de situatie dat hij geconfronteerd is met een exoneratiebeding van zijn voorman, terwijl hij deze exoneratie niet heeft kunnen 'doorgeven' aan de patiënt. Op grond van deze artikelen zou mogelijk kunnen worden voorkomen dat de voorman zich jegens de hulpverlener op het exoneratiebeding kan beroepen (vgl. Asser/Hartkamp \& Sieburgh 6-III 2014/508; Hondius, in: GS Verbintenissenrecht, art. 6:244 BW, aant. 1). 
ding jegens de producent een kortere verjarings- en vervaltermijn heeft dan een vordering van de patiënt op grond van artikel 6:77 BW. ${ }^{25}$

\section{- Ontwikkelingsrisico}

In het verlengde hiervan is de vraag of de schuldenaar op grond van artikel 6:77 BW een ontwikkelingsrisicoverweer zou moeten toekomen, daar een dergelijk verweer de producent ook toekomt. ${ }^{26}$ Of de toerekening aan de schuldenaar naar verkeersopvattingen onredelijk is indien de ongeschiktheid van de gebruikte hulpzaak het gevolg is van de verwezenlijking van een ontwikkelingsrisico, is een complexe vraag. Voor het aannemen van een ontwikkelingsrisicoverweer voor de schuldenaar in het kader van artikel 6:77 BW pleit de omstandigheid dat de aansprakelijkheid van de schuldenaar via een regresvordering alsnog zou kunnen leiden tot aansprakelijkheid van de producent. Indien de schuldenaar een dergelijke regresvordering niet kan instellen, zal zijn aansprakelijkheid groter zijn dan de aansprakelijkheid van de producent. De vraag is of hier een rechtvaardiging voor bestaat. Voor een ontkennend antwoord op deze vraag pleit de omstandigheid dat de verkoper en bezitter van een zaak evenmin aansprakelijk zijn voor een ontwikkelingsrisico. ${ }^{27}$ Relevant is bovendien dat de aansprakelijkheid van de hulpverlener voor ontwikkelingsrisico's het gebruik van nieuwe, innovatieve hulpmiddelen zou kunnen remmen en tot defensieve geneeskunde zou kunnen leiden, omdat de hulpverlener de risico's van de hulpmiddelen die reeds langer in gebruik zijn en waar hij meer ervaring mee heeft beter kan inschatten. Of dit defensieve effect echter daadwerkelijk optreedt, is een empirische vraag.

Daarentegen pleit voor een bevestigend antwoord op de vraag of er een rechtvaardiging bestaat voor de toerekening van een ontwikkelingsrisico aan de schuldenaar op grond van artikel 6:77 BW, de omstandigheid dat in het bouwrecht wordt aangenomen dat een ontwikkelingsrisico krachtens verkeersopvatting voor rekening komt van degene die de zaken kiest, hetgeen dikwijls de schuldenaar is. ${ }^{28}$

Als de schuldenaar een professionele partij is, zoals de hulpverlener, en de schuldeiser een consument, pleit dit eveneens voor de toerekening van een ontwikkelingsrisico aan de schuldenaar omdat hij beter in staat is het risico te dragen. Voor de

25. Art. 6:191 vs. art. 3:310 lid 1 jo. lid 5 BW.

26. Vgl. Rb. Amsterdam 23 januari 1992, TvGR 1992/28; Stolker 1995 , p. 688; R.P. Wijne, Aansprakelijkheid van de hulpverlener voor medische hulpzaken met 'een niet te onderkennen gebrek', L\&S 2015, afl. 4, p. 47; Zijlstra 2016, p. 452; Rb. Amsterdam 20 januari 2016, ECLI:NL: RBAMS:2016:212, r.o. 4.14.

27. Asser/Hartkamp \& Sieburgh 6-IV 2015/217; J. Hijma, Koop en ruil, WPNR 1990/5982, p. 737. Zie ook H.J. Rossel, De invloed van de regeling inzake produktenaansprakelijkheid op de ansprakelijkheid ex art. 6:173 en art. 7:24 (II, slot), WPNR 1992/6058, p. 576.

28. Betoogd is dat degene die de zaak kiest het risico beheerst; L. de Boer, Verslag van de jaarvergadering van de Vereniging voor Bouwrecht gehouden op 29 november 2002 te Utrecht, BR 2002, p. 667 e.v.; C.E.C. Jansen, Totstandkoming en inhoud van design \& constructcontracten voor complexe infrastructurele projecten (Publikatie van de Vereniging voor Bouwrecht, nr. 29), Deventer: Kluwer 2001, p. 149. hulpverlener is daarbij in de eerste plaats relevant dat artikel 7:462 BW een centrale aansprakelijkheid van het ziekenhuis in het leven roept. In de tweede plaats is van belang dat de kosten van de verwezenlijking van het risico door de hulpverlener kunnen worden verhaald op een aansprakelijkheidsverzekeraar en de kosten van de premie van die verzekering kunnen worden gespreid via de prijs van de dienst die de hulpverlener aanbiedt. De prijs van deze dienst wordt voldaan door de zorgverzekeraars, die deze kosten via de premie kunnen spreiden over alle verzekerden. Als niet de hulpverlener, maar de individueel gedupeerde patiënt het risico draagt, dan zal een deel van de schade door alleen deze patiënt worden gedragen, zoals de immateriële schade. De patiënt zal slechts een deel van zijn totale kosten op een zorgverzekeraar kunnen verhalen. Deze kosten kunnen door de zorgverzekeraar via de premie worden gespreid. De patiënt is niet in staat om de schade die hij zelf draagt te spreiden. Dit leidt tot de aanname dat er meer schade zal worden gespreid indien de hulpverlener het risico draagt. Afgezien van de economische wenselijkheid hiervan vanwege het reduceren van de impact van de schade, ${ }^{29}$ sluit dit aan bij het karakter van het ontwikkelingsrisico als een maatschappelijk risico. De maatschappij heeft baat bij de ontwikkeling van nieuwe producten. Op grond van een maatschappelijk profijtbeginsel zou kunnen worden betoogd dat de met deze ontwikkeling gepaard gaande risico's door de maatschappij dienen te worden gedragen. Dit wordt - in verhouding tot de patiënt het beste bereikt door aansprakelijkheid van de hulpverlener, omdat zoals gezegd dan de meeste schade wordt gespreid over de meeste mensen. Als de patiënt het risico draagt, wordt een deel van de schade niet door de maatschappij gedragen, maar door de individuele patiënt bij wie het risico zich (toevallig) verwezenlijkt.

- Discrepantie tussen beloning en schade

Het belang van de discrepantie tussen de beloning van de schuldenaar en de mogelijke omvang van de schade volgt uit het Vliegtuigvleugel-arrest. ${ }^{30}$ Een lage beloning tegenover een hoog schaderisico kan leiden tot onredelijkheid van toerekening aan de schuldenaar. Een dergelijke discrepantie zou denkbaar kunnen zijn in de medische context, bijvoorbeeld als een kleine, eenvoudige ingreep tot ernstige invaliditeit en omvangrijke schade kan leiden. Echter, vanwege de overige omstandigheden van het geval, zoals de eventuele centrale aansprakelijkheid van het ziekenhuis ex artikel 7:462 BW en de dekking door een aansprakelijkheidsverzekering, hoeft de aanwezigheid van een discrepantie bij de beoordeling van de redelijkheid van toerekening aan de hulpverlener niet doorslaggevend te zijn.

\section{- Verzekeringsgebruik}

Indien de schuldenaar onderdeel uitmaakt van een bedrijfs- of beroepsgroep die zich tegen dergelijke schade pleegt te verzekeren, kan dit een aanwijzing zijn dat het risico bij hem hoort

29. L. Visscher \& J. De Mot, Aansprakelijkheid voor zaken in Nederland en België: een economische analyse, AV\&S 2014/21, p. 139.

30. HR 5 januari 1968, NJ 1968/102 m.nt. G.J. Scholten (Vliegtuigvleugel). 
te liggen. ${ }^{31}$ In de beroepsgroep waartoe de hulpverlener behoort, is een aansprakelijkheidsverzekering (inmiddels) gebruikelijk.

Ook de vraag welke partij het meest aangewezen is om zich tegen het risico te verzekeren, is relevant bij de beoordeling van de redelijkheid van toerekening. In de relatie tussen de hulpverlener en de patiënt lijkt de hulpverlener de meest aangewezen partij om zich tegen de schade te verzekeren. De patiënt zal zich slechts tegen een deel van de schade die kan voortvloeien uit het gebruik van een ongeschikte medische hulpzaak kunnen verzekeren. Voor de ziektekosten, noodzakelijke hersteloperaties en vergelijkbare kosten kan een patiënt een zorgverzekering afsluiten. Deze verzekering zal echter geen andere materiële schade, zoals gederfd inkomen of aanpassingen aan de woning van gelaedeerde ten gevolge van invaliditeit, en immateriële schade dekken. Voor de overige materiële schade kan een patiënt mogelijk een ongevallenverzekering en/of arbeidsongeschiktheidsverzekering afsluiten, ${ }^{32}$ maar voor de immateriële schade kan hij zich niet verzekeren. Een hulpverlener kan een aansprakelijkheidsverzekering afsluiten, die doorgaans dekking biedt voor zowel materiële als immateriële schade.

- Wederzijdse deskundigheid van partijen

Een aanwijzing voor de verkeersopvatting ten aanzien van de redelijkheid van toerekening aan de schuldenaar op grond van artikel 6:77 BW kan ook worden gevonden in de toets van de wederzijdse deskundigheid van partijen. De omstandigheid dat de schuldenaar een professionele partij is, is een aanwijzing dat toerekening aan hem niet onredelijk is. In de literatuur is betoogd dat dit ervoor pleit dat toerekening aan een hulpverlener niet onredelijk is. Dit lijkt mij juist. Het sluit aan bij de rechtseconomische benadering van het aansprakelijkheidsrecht, waaruit een voorkeur voor een risicoaansprakelijkheid van de laedens voortvloeit als deze partij in verhouding tot de gelaedeerde een informatievoorsprong heeft. ${ }^{33}$ De relatie tussen de hulpverlener en de patiënt wordt gekenmerkt door een verschil in informatie en deskundigheid in het voordeel van de hulpverlener; het is de voornaamste reden dat de patiënt een overeenkomst met de hulpverlener sluit. Hoewel de hulpverlener geen technicus is, zal hij aanzienlijk beter op de hoogte zijn van (de eigenschappen van) de zaken die hij gebruikt dan de patiënt. In hun onderlinge verhouding is hij degene die de medische hulpzaken kiest, die getraind is in het gebruik van medische hulpzaken en die de gebruiksinstructies ontvangt en bestudeert. ${ }^{34}$

31. B.G.P. Rogmans, Verkeersopvattingen, Deventer: Kluwer 2007, p. 31-32.

32. Deze verzekeringen zullen echter dikwijls niet alle schade dekken (vgl. C.M.D.S. Pavillon \& A. Kolder, Een garantie des accidents de la vie voor Nederland?, AV\&S 2018/8, p. 31).

33. Visscher \& De Mot 2014, p. 139.

34. Vgl. Convenant Veilige Toepassing van Medische Technologie in de medisch specialistische zorg; Inspectie voor de Gezondheidszorg, Staat van de Gezondheidszorg 2008. Risico's van medische technologie onderschat, november 2008.
Als toerekening aan de hulpverlener op grond van de hoofdregel van artikel 6:77 BW zou worden afgewezen en enkel de aansprakelijkheid voor verwijtbaar handelen overblijft, zou het voor de ondeskundige patiënt die schade heeft geleden door het gebruik van een medische hulpzaak problematisch kunnen zijn om vast te stellen (1) dat de schade het gevolg is van een foutief gebruik van die zaak en niet van een gebrek in de zaak, (2) wat dit foutieve gebruik inhoudt - waarbij het niet zelden om een technologisch complexe situatie zal gaan -, en (3) dat de hulpverlener hierdoor een op hem rustende zorgplicht heeft geschonden. Dit zou niet alleen vanuit een juridisch, maar ook vanuit een rechtseconomisch perspectief onwenselijk kunnen zijn omdat het de prikkelwerking van de norm ten behoeve van de zorgvuldige omgang met hulpzaken kan frustreren als het de patiënt ervan weerhoudt een vordering in te dienen. ${ }^{35}$

- Grondslagen voor risicoaansprakelijkheid De toerekening aan de schuldenaar op grond van de hoofdregel van artikel 6:77 BW is een toerekening op grond van risico. Derhalve kan bij de vraag of toerekening aan de schuldenaar in een bepaald geval (on)redelijk is, steun worden gezocht in de grondslagen voor de (buitencontractuele) risicoaansprakelijkheden van het BW. ${ }^{36}$ Een groot aantal grondslagen voor de (buitencontractuele) risicoaansprakelijkheden van het BW zijn ook toepasbaar op de aansprakelijkheid van de hulpverlener voor het gebruik van hulpzaken:

- de profijttheorie (de hulpverlener kan anno 2019 alleen nog diensten verlenen als hij medische zaken gebruikt);

- de verzekerbaarheid (reeds besproken onder het kopje 'Verzekeringsgebruik');

- risicospreiding (reeds besproken onder het kopje 'Onwikkelingsrisico');

- de draagkrachttheorie (indien de hulpverlener een ziekenhuis is of een arts die binnen een ziekenhuis opereert en de schuldeiser is een patiënt (en geen zorgverzekeraar), dan is de hulpverlener de meer draagkrachtige partij); ${ }^{37}$ en

- de gevaarzettingsleer (de hulpverlener brengt het risico in de overeenkomst door de zaak te kiezen en te gebruiken bij de uitvoering van zijn verbintenis; de invloed van de patiënt op die keuze is dikwijls non-existent).

De toepasselijkheid van deze grondslagen zou een aanwijzing kunnen bevatten dat het risico dat voortvloeit uit het gebruik van ongeschikte hulpzaken krachtens verkeersopvattingen voor rekening van de hulpverlener dient te komen.

35. Visscher \& De Mot 2014, p. 139.

36. De volgende grondslagen kunnen worden onderscheiden: de gevaarzettingsleer (art. 6:170, 6:173, 6:175-177 en 6:179 BW), de profijttheorie (art. 6:76, 6:170 en 6:175 BW), de draagkracht van partijen, de verzekerbaarheid (art. 6:170 en 6:173 BW), de spreiding van kosten (art. 6:170 en 6:175 BW), de eenheidsgedachte (art. 6:170, 6:171, 6:175 en 6:181 BW) en de activiteitstheorie (art. 6:76 BW).

37. De onderlinge draagkracht van partijen kan niet als enige grondslag voor de vestiging of afwijzing van aansprakelijkheid gelden en enkel als nevenargument meewegen bij de beoordeling van de mogelijke (on)redelijkheid van toerekening. 


\subsubsection{Overige omstandigheden van het geval}

- De aard van de ongeschiktheid

Bij de overige omstandigheden van het geval valt te denken aan de aard van de ongeschiktheid en de aanwezigheid van een keurmerk. De aard van de ongeschiktheid ziet op de vraag of de zaak in het algemeen of incidenteel ongeschikt is. In de jurisprudentie inzake de aansprakelijkheid voor een ongeschikte medische hulpzaak is naar voren gekomen dat de incidentele ongeschiktheid van een in het algemeen geschikte zaak een beroep op de tenzij-formule rechtvaardigt. ${ }^{38}$ In de jurisprudentie inzake de ansprakelijkheid voor een ongeschikte niet-medische hulpzaak wordt dit standpunt afgewezen en ook in de literatuur wordt de opvatting verdedigd dat het toepassingsbereik van de hoofdregel van artikel 6:77 BW zich uitstrekt naar zowel algemeen als incidenteel ongeschikte hulpzaken. ${ }^{39}$ Een redenering waarin het incidentele karakter van de ongeschiktheid relevant wordt bevonden, zal snel neigen naar een redenering voor het ontbreken van verwijtbaarheid, hetgeen niet aansluit bij het karakter van artikel 6:77 BW.

- De aanwezigheid van een keurmerk

In de jurisprudentie inzake medische en niet-medische hulpmiddelen is tevens op verschillende manieren omgegaan met de aanwezigheid van een keurmerk. ${ }^{40}$ Indien wordt aangenomen dat ook incidentele ongeschiktheid onder het toepassingsbereik van artikel 6:77 BW valt, dan zal de aanwezigheid van een keurmerk doorgaans niet relevant zijn, aangezien dit hooguit iets kan zeggen over de algemene deugdelijkheid van de productserie en onverlet laat dat een individuele zaak incidenteel kan falen. Bovendien strekt een dergelijk keurmerk er niet toe (rechts)personen die dit product verkopen of hanteren van aansprakelijkheid te disculperen. Daarnaast is de vraag of de hulpverlener voldoende zorg in acht heeft genomen door een medische zaak met een keurmerk aan te schaffen niet relevant voor de risicoafweging die plaats dient te vinden in het kader van artikel 6:77 BW. ${ }^{41}$

\subsection{Rechtsvergelijking}

Uit een analyse van het Duitse, Franse en Engelse recht is een aantal relevante bevindingen voortgekomen. In de eerste plaats ten aanzien van de vraag of het zijn van hulpverlener onverenigbaar is met aansprakelijkheid op grond van risico. De Nederlandse discussie over de aansprakelijkheid van de hulpverlener op grond van artikel 6:77 BW hangt in belangrij-

38. Hof Amsterdam 7 januari 1988, TvGR 1989/99; Rb. 's-Hertogenbosch 21 juli 2010, L\&S 2011/125.

39. Rb. Utrecht 25 juli 2012, ECLI:NL:RBUTR:2012:BX3544; Rb. Midden-Nederland 12 november 2014, ECLI:NL:RBMNE:2014:5643.

40. Rb. Zeeland-West-Brabant 15 januari 2014, ECLI:NL:RBZWB: 2014:3600; Rb. Rotterdam 19 augustus 2015, ECLI:NL:RBROT: 2015:6179; Rb. Amsterdam 20 januari 2016, ECLI:NL:RBAMS: 2016:212; Rb. Amsterdam 24 mei 2017, ECLI:NL:RBAMS:2017:3491; Rb. Limburg 31 mei 2017, ECLI:NL:RBLIM:2017:4981; Rb. Utrecht 25 juli 2012, ECLI:NL:RBUTR:2012:BX3544; Rb. Midden-Nederland 12 november 2014, ECLI:NL:RBMNE:2014:5643.

41. Vgl. Rb. Amsterdam 20 januari 2016, ECLI:NL:RBAMS:2016:212; Rb. Amsterdam 24 mei 2017, ECLI:NL:RBAMS:2017:3491. ke mate samen met deze vraag. Rechtsvergelijking toont aan dat dit niet per definitie het geval is. Ook in Frankrijk en Engeland kan de hulpverlener onder omstandigheden zonder schuld aansprakelijk zijn voor de schade die een patiënt heeft geleden door een ongeschikte medische zaak. ${ }^{42}$

In de tweede plaats is relevant dat in elk van de onderzochte landen naar voren komt dat op de hulpverlener niet slechts inspanningsverplichtingen, maar ook resultaatsverplichtingen kunnen rusten ten aanzien van de medische zaken die hij gebruikt of levert aan de patiënt. ${ }^{43}$ Dit is relevant omdat in de Nederlandse literatuur en jurisprudentie dikwijls naar voren komt dat op een hulpverlener enkel inspanningsverplichtingen rusten en het aannemen van een risicoaansprakelijkheid om die reden onredelijk is.

Tot slot is interessant dat rechtsvergelijking met Engeland en Duitsland de voor de patiënt mogelijk nadelige gevolgen van een schuldaansprakelijkheid van de hulpverlener voor het gebruik van medische hulpzaken weergeeft. Dit is relevant omdat de hulpverlener enkel aansprakelijk is op grond van schuld indien hij categorisch zou worden uitgezonderd van de hoofdregel van artikel 6:77 BW. De Engelse hulpverlener die in een publiek ziekenhuis schade heeft veroorzaakt door het gebruik van een medische zaak, is enkel aansprakelijk indien hij een zorgplicht heeft geschonden. ${ }^{44}$ Dat er bij schade ten gevolge van het gebruik van een medische zaak vaak geen sprake zal zijn van een zorgplichtschending en dat het, indien dit wel het geval is, voor de patiënt lastig zal zijn te onderscheiden of hij schade heeft geleden door het falen van de zaak of door een fout van de hulpverlener, maakt dat een vordering van de patiënt jegens de hulpverlener niet snel kansrijk zal zijn. ${ }^{45}$ Dit heeft tot gevolg dat er vrijwel geen jurisprudentie bestaat over de aansprakelijkheid van de Engelse publieke hulpverlener voor het gebruik van een ongeschikte medische zaak. In Duitsland is de hulpverlener eveneens enkel aansprakelijk indien hij een zorgplicht heeft geschonden. ${ }^{46}$ De Duitse patiënt wordt echter geholpen door een bewijslastomkering indien zijn schade het gevolg is van de verwezenlijking van een risico dat voortvloeit uit het gebruik van een medische zaak. ${ }^{47}$ Hoewel in Duitsland - anders dan in Engeland - wel enige jurisprudentie bestaat over de aansprakelijkheid van de hulpverlener voor het gebruik van een medische zaak, is een vordering van de patiënt zelden succesvol. ${ }^{48}$ Dit betekent dat, als de producent geen verhaal biedt, de patiënt de schade draagt van het

42. In Frankrijk: als de hulpverlener een publieke zorginstelling is of opereert vanuit een publieke instelling (zie bijv. Conseil d'État 15 november 2017, 403317). In Engeland: als de hulpverlener een privékliniek is of opereert vanuit een privékliniek en er sprake is van transfer van een medische zaak, zoals een implantaat of prothese, aan de patiënt (op grond van de Consumer Rights Act 2015). Zie uitgebreid Hiemstra 2018, hoofdstuk 6 en 7.

43. Zie uitgebreid Hiemstra 2018, hoofdstuk 5-7.

44. Op grond van negligence.

45. Vgl. Brazier v. Ministry of Defence [1965] 1 Lloyd's Rep 26.

46. Op grond van $₫ 280$ lid 1 BGB jo. $\$ 276$ lid 2 BGB of $\$ 823$ BGB.

47. \$630h BGB

48. Hiemstra 2018, p. 204 e.v 
gebruik van een ongeschikte medische zaak door de hulpverlener.

\section{Conclusie}

Een analyse van de omstandigheden die relevant kunnen zijn bij de toepassing van artikel 6:77 BW heeft uitgewezen dat ook in de medische context een risicoaansprakelijkheid dient te gelden voor het gebruik van ongeschikte hulpzaken. Een schuldenaar dient op grond van de tenzij-formule niet categorisch te worden uitgezonderd van toepassing van de hoofdregel van artikel 6:77 BW vanwege zijn hoedanigheid als hulpverlener. Hierbij is van belang dat de hulpverlener profijt heeft van het gebruik van hulpzaken, hij als professionele partij de schade kan spreiden en de patiënt dit als consument niet kan, en hij doorgaans de meer draagkrachtige partij is in verhouding tot de patiënt vanwege de gecentraliseerde aansprakelijkheid van het ziekenhuis. Bovendien bestaat er een praktijk van verzekeren in de medische beroepsgroep en biedt de verzekering van de hulpverlener een grotere dekking dan de verzekering van de patiënt. Daarnaast bevatten de deskundigheid van de hulpverlener in verhouding tot de ondeskundigheid van de patiënt, de hoogte van de tegenprestatie en de omstandigheid dat de hulpverlener het risico op schade in het leven roept door de betreffende zaak te kiezen, kopen en gebruiken voor de uitvoering van zijn verbintenis, terwijl de invloed van de patiënt daarop afwezig dan wel verwaarloosbaar is, aanwijzingen dat het risico krachtens verkeersopvattingen voor rekening van de hulpverlener dient te komen.

De rechtsvergelijking heeft aangetoond dat de hulpverlener ook in andere stelsels onder omstandigheden risicoaansprakelijk kan zijn voor de schade die een patiënt heeft geleden door een medische hulpzaak. Ook vanuit een rechtseconomisch perspectief is een risicoaansprakelijkheid van de hulpverlener wenselijk. ${ }^{49}$

De MvA bij artikel 6:77 BW, waarin een kanalisatie naar de producent wordt geïmpliceerd, doet aan het aannemen van een risicoaansprakelijkheid van de hulpverlener niet af. De mogelijke aansprakelijkheid van de producent dient vanuit een systematisch, rechtseconomisch en beschermingsperspectief niet tot disculpatie van de hulpverlener te leiden. Anders dan in de jurisprudentie veelvuldig naar voren komt, kan de kwalificatie van de verbintenis van de hulpverlener als inspannings- of resultaatsverbintenis evenmin tot een ander oordeel leiden. Een overeenkomst, en zo ook een geneeskundige behandelingsovereenkomst, bevat veelal zowel inspanningsals resultaatsverplichtingen voor de schuldenaar. Deze kwalificatie is enkel relevant bij het vaststellen van de tekortkoming; bij de toerekenbaarheid in het kader van artikel 6:77 BW is deze kwalificatie niet relevant.

Ook de aanwezigheid van een keurmerk kan niet leiden tot een succesvol beroep van de hulpverlener op de tenzij-formule, omdat een dergelijk keurmerk er niet toe strekt (rechts)personen die dit product verkopen of hanteren van aansprakelijkheid te disculperen. Bovendien is de vraag of de hulpverlener voldoende zorg in acht heeft genomen door een medische zaak met een keurmerk aan te schaffen niet relevant voor de risicoafweging die plaats dient te vinden in het kader van artikel 6:77 BW. Ook zal de procedure ter verkrijging van een keurmerk enkel een papieren toets behelzen en zal de aanwezigheid van een keurmerk hooguit iets zeggen over de geschiktheid van de zaak in het algemeen, terwijl ook incidentele ongeschiktheid onder het toepassingsbereik van artikel 6:77 BW valt.

Toerekening aan de hulpverlener zal wel onredelijk zijn indien zijn keuzevrijheid door de patiënt is beperkt en hij geen waarschuwingsplicht heeft geschonden. In een dergelijk geval dient het risico voor rekening van de patiënt te komen, die met zijn keuze dit risico in het leven heeft geroepen. Mogelijk kan toerekening aan de hulpverlener eveneens onredelijk worden geacht indien de schade het gevolg is van de verwezenlijking van een ontwikkelingsrisico.

Het risico dat voortvloeit uit het gebruik van een hulpzaak dient in beginsel voor rekening van de hulpverlener te komen. De tenzij-formule betreft een redelijkheidsexceptie en de redelijkheid zal niet snel gebieden dat het risico voor rekening van een consument, zoals een patiënt, moet komen in plaats van voor rekening van een professionele opdrachtnemer, zoals een hulpverlener.

49. Hiemstra 2018, p. 279 e.v. 